\title{
Sun Valley
}

\section{Bruce Cameron}

Sun Valley is located within the Blue Mountains City Council local government area, hidden in the lower Blue Mountains near Springwood.

The valley is the result of a strange geological formation known as a diatreme or volcanic vent. These volcanic remains have formed a landscape that is unique in the Blue Mountains. The surrounding sandstone is dry and rugged, while very rich soils and undulating country have provided excellent native grasslands and magnificent stands of mountain blue gum trees.

\section{Original occupants}

The first people to visit Sun Valley were the Aboriginal clans crossing, and living in, the Blue Mountains. It is possible that both Dharug and Gundungurra people used the valley.

There are many Aboriginal sites in the valley and in the surrounding creeks and gullies. Stone tools - including hatchets, scrapers and core material - have been located all around the valley. Stone axe grinding grooves and cave art sites have also been recorded.

The local Aboriginal clans would bring raw stone material up from the lowlands of the Nepean River gravel beds and fabricate these stones into working tools. Open surface scatters of waste flake material and abandoned tools occur in numerous locations around Sun Valley, with basalt, chert and quartz artefacts littering the ground at major Aboriginal camp sites. One site has both axe grinding grooves and stone artefacts, proving that high density sites existed here due to the abundance of water, food and raw material such as rock platforms and water-filled potholes to sharpen basalt pebbles into stone hatchets.

Around the sandstone rim of Sun Valley, where volcanic soils meet the sandstone on the contact zone, occupation shelters occur in the rock overhangs. A number of these sites have excellent examples of Sydney sandstone rock art, including hand stencils and simple figurative charcoal art, most of which are in almost pristine condition.

\section{The arrival of Europeans}

The first recorded European activity in Sun Valley was a visit in 1813 by the well-known explorers Blaxland, Wentworth and Lawson. They rested their horses in the valley and camped the night under the stands of blue gums. There is little doubt other Europeans had visited the location, as Blaxland recorded in his journal that trees in the area had been cut with an axe. 
A year after the official crossing of the mountains in 1813, William Cox, the famous road builder, used Sun Valley as a camp for his men and horses. Around this time the location was simply known as The Valley.

The Superintendent of the government agricultural farm at Emu Plains, Richard Fitzgerald, used The Valley for fattening stock, and for a period the place became known as Fitzgerald's Valley. The main creek running through Sun Valley is now named for Fitzgerald.

In 1834, a map drawn by Sir Thomas Mitchell clearly shows the location as The Valley, just below Springwood. Old coins and other artefacts found over the years in the valley indicate usage was constant and that people crossing the mountains used the valley as a resting place. Anecdotal information suggests many of the crowds heading for the western gold fields camped the night in Sun Valley. It became well known as a location to water horses, and for providing good camping and drinking water.

\section{Farming and logging in The Valley}

After the mid-1800s, the valley became a working farm and supported stock and market gardening. For many years the area was also known as Deane's Valley, the land being owned by William Deane. Another Deane family owned a house in Sun Valley named Greenacres (after the valley environment) and a third Deane associated with Sun Valley was Henry Deane the botanist. The mighty mountain blue gum (Eucalyptus deanei) was named after Henry Deane when he first located and described the tree in The Valley in 1888, in recognition of his work in identifying a new genus.

The area was logged for timber for many years, and a small railway line was constructed to winch and haul logs out of the valley. In the early days of timber-getting, bullocks were also used to extract logs from deep within the bush. Reminders of the timber-getting days can still be found hidden around the valley. Old cables, implements and machinery still litter the bush at the old logging camps.

\section{Sun Valley is subdivided}

In the 1960s, the land was subdivided into small acreages, with the real estate company creating the new name of Sun Valley. It was known for many years as part of Valley Heights, the name given to the land above The Valley. In the late 1990s, the Geographical Names Board agreed to officially name the location Sun Valley.

Sun Valley has become a small rural community tucked away off the main Blue Mountains ridge and the Great Western Highway. Many reminders of the past still remain deep within the bush - a red hand stencil in a cave shelter from the first locals, old ploughs from the early farming days and old tree stumps with board slots cut into them. 
These reminders - both Aboriginal and European - provide a colourful snapshot of the history of this ancient volcanic vent that has supported a range of human occupation for many thousands of years.

Bruce Cameron is a local historian and bushwalker

\section{References}

George Mackeness, (ed), Fourteen Journeys over the Blue Mountains NSW 1813-1841, HorwitzGrahame, Sydney, 1965

Chris Cunningham, The Blue Mountains rediscovered: beyond the myths of early Australian exploration, Kangaroo Press, Kenthurst NSW, 1996

Bruce Cameron, Sun Valley and Long Angle Gully: A history, the author, Valley Heights NSW, 1998 